Computers and Geotechnics. 2016. Vol. 77. P. 45-55. doi: http:// doi.org/10.1016/j.compgeo.2016.04.001

8. Development and application of a pseudo-3D pit slope displacement map derived from ground-based radar / Severin J. et. al. // Engineering Geology. 2014. Vol. 181. P. 202-211. doi: http://doi.org/10.1016/j.enggeo.2014.07.016

9. Osasan K. S., Stacey T. R. Automatic prediction of time to failure of open pit mine slopes based on radar monitoring and inverse velocity method // International Journal of Mining Science and Technology. 2014. Vol. 24, Issue 2. P. 275-280. doi: http://doi.org/10.1016/j.ijmst.2014.01.021

10. Stability analysis of seismic slopes with cracks / Zhao L.-H. et. al. // Computers and Geotechnics. 2016. Vol. 77. P. 77-90. doi: http://doi.org/10.1016/j.compgeo.2016.04.007

11. Stability analysis of slopes with ground water during earthquakes / Lu L. et. al. // Engineering Geology. 2015. Vol. 193. P. 288-296. doi: http://dx.doi.org/doi:10.1016/j.enggeo.2015.05.001

12. Gariano S. L., Guzzetti F. Landslides in a changing climate // Earth-Science Reviews. 2016. Vol. 162. P. 227-252. doi: http:// doi.org/10.1016/j.earscirev.2016.08.011

13. Sadovenko Y. A., Podvyhyna E. O., Zahrytsenko A. N. Dyfferentsyatsyia faktorov ustoichyvosty tekhnohenno nahruzhennikh lessovikh sklonov metodom matematycheskoho modelyrovanyia fyltratsyonnikh protsessov // Visnyk Odeskoho natsionalnoho universytetu. Seriia: Heohrafichni ta heolohichni nauky. 2013. Vol. 18, Issue 1. P. 147-154.

14. Influence of watering filled-up rock massif on geomechanical stability of the cyclic and progressive technology line / Kovrov O. et. al. // Mining of Mineral Deposits. 2016. Vol. 10, Issue 2. P. 55-63. doi: http://doi.org/10.15407/mining10.02.055

15. Sdvyzhkova E. A., Kovrov A. S., Kyryiak K. K. Heomekhanycheskaia otsenka ustoichyvosty opolznevoho sklona metodom konechnikh elementov // Naukovyi visnyk Natsionalnoho hirnychoho universytetu. 2014. Vol. 2. P. 86-92.

Kovrov Oleksandr, PhD, Associate Professor, Professor of the Department of Ecology and Environmental Protection Technologies, National Technical University «Dnipro Polytechnic», Ukraine, ORCID: http://orcid.org/0000-0003-3364-119X, e-mail: kovralex1@gmail.com

Kolesnyk Valerii, Doctor of Technical Sciences, Professor, Department of Ecology and Environmental Protection Technologies, National Technical University «Dnipro Polytechnic», Ukraine, ORCID: http:// orcid.org/0000-0003-2349-3576, e-mail: kolesnikve@yahoo.com

\section{Shuryberko M., Gomelya M., Gluchenko N., Chuprova K., Overchenko T.}

\title{
DEVELOPMENT OF NEW COMPOSITIONS FOR REDUCING THE CORROSIVE AGGRESSIVENESS OF OIL-CONTAINING WATER
}

Об'єктом дослідження є екологічно безпечні системи в нафтовидобувній та нафтопереробній промисловості. Всі стадії нафтокористування - видобування-переробка-використання - супроводжуються забрудненням довкілля. Суттєві забруднення виникають при видобуванні, транспортуванні та розливі нафти, скиді стічних вод, спалюванні та зберіганні нафтових відходів. Через наявність агресивних складових у складі нафтовмісних мінералізованих вод зростає швидкість корозї металевих конструкиій, що призводить до швидкого руйнування обладнання та трубопроводів. Тому одним з першочергових завдань $\epsilon$ захист металевих конструкцій від корозї у нафті та водонафтових емульсіях.

В роботі проведено оцінку агресивності водних розчинів різного нафто-мінерального складу при температурі $80^{\circ} \mathrm{C}$. Показано, що мінералізовані водні розчини є більш корозійно агресивними, аніж іх композицї з нафтою. Розроблено композиції для зниження корозійної агресивності нафтовмісних вод та визначено їх ефективність. Результати досліджень вказують, що інгібітор на основі алкілімідазоліну забезпечує високу ефективність захисту сталі від корозії при температурах від $30^{\circ} \mathrm{C}$ до $80^{\circ} \mathrm{C}$. Ступінь захисту при дозах

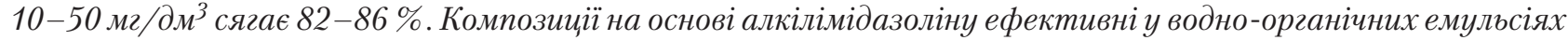
на основі мінералізованої води та петролейного ефіру лише за невисоких температур. При підвищених температурах, за рахунок високої летючості петролейного ефіру, формування захисної адсорбиійної плівки на поверхні сталі не відбувається.

В разі застосування інгібіторів корозї сталі на основі алкілімідазолінів можливо досягти високої ефективності захисту від руйнування як нафтопроводів, де, крім нафти, завжди присутні домішки мінералізованої води, так і водопроводів, де у високомінералізованих водах присутні домішки нафти. Перевагою алкілімідазолінів є те, що за рахунок гідрофільної та гідрофобної складових їхніх молекул вони добре розчиняються як у нафтопродуктах, так і у водному середовищі.

Ключові слова: нафтовмісні води, корозія металу, інгібітор корозї, швидкість корозії, алкілімідазолін.

\section{Introduction}

The aggressive impact of corrosive environments leads to increased corrosion of equipment, tanks, pipes and pipe fittings [1].
The corrosive aggressiveness of the water-oil emulsion varies depending on the composition of the aqueous phase, its ratio to the hydrocarbon phase, the composition and amount of gaseous substances. In the development of oil fields from the well to the surface enters the oil-gas-water 
mixture, which consists of oil, petroleum gas and produced water. Oil and oil gas are subject to further purification (removal of mechanical impurities, salts, hydrogen sulfide, carbon dioxide, etc.), and separated formation water is utilized for various needs of the field.

The corrosive aggressiveness of the components released during the processing of oil depends on their chemical composition and other factors.

Hydrocarbon gas, separated from oil, consists of a mixture of saturated hydrocarbons, which are not dangerous in terms of corrosion. These gases contain impurities of hydrogen sulfide and carbon dioxide, and during the extraction and processing of oil, oxygen is also added to their composition. Therefore, in this case, the corrosion processes are particularly intense.

By its dielectric properties, gas condensate is close to oil, but in the presence of hydrogen sulfide, carbon dioxide, oxygen and water, it becomes corrosive.

The sulfur content in most oils does not exceed $0.5 \%$. In petroleum, sulfur can be in the free state in the form of hydrogen sulfide and sulfur organic compounds.

Produced waters contain a large amount of impurities (chlorides, sulphates, carbonates of alkali and alkalineearth metals) and are complex multicomponent systems. Accordingly, they have a high electrical conductivity, which contributes to the intensive flow of electrochemical corrosion. The corrosive effect of water on construction materials depends on the overall mineralization of water [2]. In hard water, the formation of a protective lime film is more likely [3] than in soft water, so hard waters are less aggressive than soft waters in relation to steel. In addition, the formed corrosion products in the form of precipitates of sulfides and iron oxides have high abrasive properties and enhance corrosion in the water flow.

Oil products, which are used in various industries, also have high corrosive aggressiveness. For example, nefras oil solvents, which are characterized by:

- ability to remove organic pollution from the surface of metals;

- dissolve quickly;

- to form a minimum amount of deposits and due

to the presence of sulfur compounds in solvents, they

have a high corrosive aggressiveness.

As can be seen from the above, through a wide qualitative and quantitative spectrum of the composition of solutions, the problem of combating steel corrosion in a water-oil medium is quite complex and relevant. Therefore, studies on the search for effective compositions to reduce the corrosivity of oil-contained water, depending on their oil and mineral composition and determine the optimal parameters, are relevant.

\section{The object of research and its technological audit}

The object of research is environmentally friendly systems in the oil and petrochemical industry.

All stages of the oil use - mining, processing, use - are accompanied by environmental pollution [4, 5]. Significant pollution occurs during the extraction, transportation and spill of oil, wastewater discharge, burning and storage of oil waste. Most of the known methods of disposal of oil waste are focused on the use of powerful expensive equipment. Accordingly, the development of new technologies for the neutralization and reduction of the hazard class of oil-containing emulsions is an important scientific and practical task.

On the other hand, due to the presence of aggressive components in the composition of oil saline water (hydrogen sulfide, carbon dioxide, etc.), the corrosion rate of metal structures increases, which leads to the rapid destruction of equipment and pipelines. And as a result, the risk of an unexpected release of oil and oil products into the environment significantly increases. In addition, increased corrosion aggressiveness of mineralized media leads to significant material and energy costs.

Therefore, one of the priorities is protection of metal structures from corrosion in oil and oil-water emulsions.

One of the ways to solve this problem is the selection and application of metal corrosion inhibitors at all stages of the oil use. The main requirements for promising inhibitors are their high efficacy, non-toxicity and low cost [1, 2].

\section{The aim and objectives of research}

The aim of research is development of compositions to reduce the corrosivity of oil-containing water and determine their effectiveness. To achieve this aim it is necessary to perform the following objectives:

1. To determine the corrosion rate of steel 20, depending on the chemical composition of aqueous solutions at a temperature of $80{ }^{\circ} \mathrm{C}$.

2. To assess the effectiveness of alkyl imidazolines in order to reduce the corrosion rate of metal for environments of different water-oil composition.

3. To establish the influence of the chemical composition of the initial water-organic solutions and the proposed compositions to reduce the corrosion rate of the metal.

\section{Research of existing solutions of the problem}

The danger of corrosion processes accompanies practically all industries, in particular, circulating cooling systems of enterprises [1, 2]. Through a special organo-mineral composition of media, the corrosion of equipment used in the extraction of oil and natural gas is characterized by certain differences [4, 5].

The main effective way to combat corrosion is the use of metal corrosion inhibitors [6, 7].

One of the reasons that exist when developing oil fields from a well is the vertical position of the pipes in the oil fields. Even with the use of new reagents, the effect of inhibition may be insignificant. This is due to the complication of the spread of corrosion inhibitors and precipitation stabilizers along the entire length of the pipe [8]. To improve the depth of the inhibitor, capsules are developed from calcium alginate gel, which, in addition to the inhibitor, contain heavy addition of $\mathrm{BaSO}_{4}$.

In addition, the process of inhibition of pipes in oil production is complicated by high depth temperatures $\left(>150{ }^{\circ} \mathrm{C}\right)$ and pressures $(>1020.6895 \mathrm{~atm}$.$) , high content$ of dissolved substances. With the development of offshore oil and gas production in ultra-deep water, more and more wells are exposed to extremely high temperature and pressure under anodic conditions. To prevent the pipes from corroding and scaling, namely siderite $\left(\mathrm{FeCO}_{3}\right)$ and iron oxide $\left(\mathrm{Fe}_{2} \mathrm{O}_{3}\right)$, the use of sulfonated polycarboxylic acid, 
polyvinyl sulfonate, carboxymethyl inulin and sodium citrate in such harsh conditions [9].

Inhibitors of oil fields have been used for decades to combat carbonate and sulphate scale, as well as pipe corrosion [10]. However, only a few of them demonstrate good biodegradation, which makes them environmentally acceptable in areas with harsh requirements. It is proposed to use a new class of polycarbonate polymers with carboxylate and phosphonate groups as potential inhibitors of oil fields [11]. These compositions provide for the inhibition of scale in the form of calcite and barite in both new and scale-coated tubes at $130{ }^{\circ} \mathrm{C}$.

Reducing the corrosivity of water containing petroleum products is also associated with certain difficulties, the main of which is the diversity of the chemical (fractional) composition. For example, petroleum ether cannot be assigned a reagent qualification, since it does not have a main component for rationing.

Based on the analysis of literature data, it can be concluded that the protection of wells against corrosion and scale during oil production is a really complex and multifaceted process.

New compositions in oil production and refining should be complex, that is, at the same time reduce the corrosivity of the environment and reduce sedimentation, be able to work at high temperatures and be environmentally friendly.

\section{Methods of research}

It is known [10] that aromatic nitrogen-containing compounds have inhibiting properties on metal corrosion in corrosive environments. Although alkyl imidazolines, when exposed to atmospheric moisture at elevated temperatures, may slowly hydrolyze to amido-amines, a change in the chemical composition of the inhibitor does not affect its effectiveness under conditions of carbon dioxide and hydrogen sulfide corrosion. Therefore, compositions based on alkyl imidazolines are developed and their effectiveness in protecting steel 20 from corrosion by the massometric method is determined.

Massometric determination of the corrosion rate was carried out in stationary media according to the difference in mass of the sample, corroded, in grams, before and after corrosion. The duration of the experiments was 9 hours at $30{ }^{\circ} \mathrm{C}$ and 5 hours at $80{ }^{\circ} \mathrm{C}$.

Massometric indicator of corrosion, $\mathrm{g} /\left(\mathrm{m}^{2} \cdot \mathrm{h}\right)$ :

$$
K_{m}=\frac{\left(m_{1}-m_{2}\right)}{S \cdot \tau},
$$

where $m_{1}$ - the initial mass of the sample, $g ; m_{2}$ - the mass of the sample after the test, g; $S$ - the sample area, $\mathrm{m}^{2}$; $\tau$ - the test duration, h.

On the basis of the calculated values of massometric indicators of corrosion, the drag coefficient and the degree of protection against corrosion are determined.

Drag coefficient (DC):

$$
K_{D}=\frac{W^{o}}{W_{i}},
$$

where $W^{o}$-massometric indicator of corrosion without the use of an inhibitor, $\mathrm{g} /\left(\mathrm{m}^{2} \cdot \mathrm{h}\right) ; W_{i}$ - massometric indicator of corrosion on the use of the inhibitor, $\mathrm{g} /\left(\mathrm{m}^{2} \cdot \mathrm{h}\right)$.
The degree of protection against corrosion, \%:

$$
Z=\left(1-\frac{1}{K_{D}}\right) \cdot 100 .
$$

Model solutions based on distilled or tap water with the addition of $\mathrm{NaCl}\left(30 \mathrm{~g} / \mathrm{dm}^{3}\right.$ or $\left.100 \mathrm{~g} / \mathrm{dm}^{3}\right), \mathrm{CH}_{3} \mathrm{COOH}$ $\left(\mathrm{g} / \mathrm{dm}^{3}\right)$ and oil or petroleum ether are used as the medium.

\section{Research results}

At the first stage of research, the influence of the chemical composition of aqueous solutions on the corrosion rate of steel 20 (Table 1) is determined.

Table 1

\begin{tabular}{|c|c|c|}
\hline Model solution & Type of solution & $\begin{array}{c}\text { Corrosion rate, } W \text {, } \\
\mathrm{g} /\left(\mathrm{m}^{2} \cdot \mathrm{h}\right)\end{array}$ \\
\hline $\begin{array}{l}77 \mathrm{~cm}^{3} \text { of mineralized water: } \\
\text { - distilled water; } \\
-30 \mathrm{~g} / \mathrm{dm}^{3} \text { of } \mathrm{NaCl} \text {; } \\
-3 \mathrm{~g} / \mathrm{dm}^{3} \text { of } \mathrm{CH}_{3} \mathrm{COOH}\end{array}$ & P-1 & 4.0352505 \\
\hline $\begin{array}{l}77 \mathrm{~cm}^{3} \text { of mineralized water: } \\
\text { - distilled water; } \\
-30 \mathrm{~g} / \mathrm{dm}^{3} \text { of } \mathrm{NaCl} ; \\
-3 \mathrm{~g} / \mathrm{dm}^{3} \text { of } \mathrm{CH}_{3} \mathrm{COOH} ; \\
-500 \mathrm{~g} / \mathrm{dm}^{3} \text { of } \mathrm{Na}_{2} \mathrm{SO}_{3}\end{array}$ & P-2 & 2.643785 \\
\hline $\begin{array}{l}77 \mathrm{~cm}^{3} \text { of mineralized water: } \\
\text { - distilled water; } \\
-30 \mathrm{~g} / \mathrm{dm}^{3} \text { of } \mathrm{NaCl} ; \\
-3 \mathrm{~g} / \mathrm{dm}^{3} \text { of } \mathrm{CH}_{3} \mathrm{COOH} ; \\
-23 \mathrm{~cm}^{3} \text { of oil }\end{array}$ & P-3 & 2.820036 \\
\hline $\begin{array}{l}77 \mathrm{~cm}^{3} \text { of mineralized water: } \\
\text { - distilled water; } \\
-30 \mathrm{~g} / \mathrm{dm}^{3} \text { of } \mathrm{NaCl} ; \\
-3 \mathrm{~g}^{3} \mathrm{dm}^{3} \text { of } \mathrm{CH}_{3} \mathrm{COOH} ; \\
-23 \mathrm{~cm}^{3} \text { of oil }\left(30^{\circ} \mathrm{C}\right)\end{array}$ & P-3* & 0.320234 \\
\hline $\begin{array}{l}77 \mathrm{~cm}^{3} \text { of mineralized water: } \\
- \text { tap water; } \\
-30 \mathrm{~g} / \mathrm{dm}^{3} \text { of } \mathrm{NaCl} ; \\
-3 \mathrm{~g} / \mathrm{dm}^{3} \text { of } \mathrm{CH}_{3} \mathrm{COOH} ; \\
-23 \mathrm{~cm}^{3} \text { of oil }\end{array}$ & P-4 & 4.71243 \\
\hline $\begin{array}{l}77 \mathrm{~cm}^{3} \text { of mineralized water: } \\
\text { - tap water; } \\
-100 \mathrm{~g} / \mathrm{dm}^{3} \text { of } \mathrm{NaCl} \text {; } \\
-3 \mathrm{~g} / \mathrm{dm}^{3} \text { of } \mathrm{CH}_{3} \mathrm{COOH} ; \\
-23 \mathrm{~cm}^{3} \text { of oil }\end{array}$ & P-5 & 5.510204 \\
\hline
\end{tabular}

The dependence of the corrosion rate of steel 20 on the chemical composition of aqueous solutions at a temperature of $80^{\circ} \mathrm{C}$

Note: ${ }^{*}$ - solution temperature $-30^{\circ} \mathrm{C}$

As can be seen from the above results (Table 1), saline solutions (distilled water, $30 \mathrm{~g} / \mathrm{dm}^{3}$ of $\mathrm{NaCl}, 3 \mathrm{~g} / \mathrm{dm}^{3}$ of $\mathrm{CH}_{3} \mathrm{COOH}$ ) are characterized by high corrosivity. The corrosion rate of such a solution is $4.0352505 \mathrm{~g} /\left(\mathrm{m}^{2} \cdot \mathrm{h}\right)$. The presence of sodium sulfite reduces the aggressiveness of water by 1.5 times $\left(W=2.6443785 \mathrm{~g} /\left(\mathrm{m}^{2} \cdot \mathrm{h}\right)\right)$ due to the binding of sodium sulfite dissolved in water by oxygen.

Oil itself has an inhibitory effect. So, when oil is added to a saline solution (solution:oil - 3.35:1), the corrosion rate of steel at a temperature of $80^{\circ} \mathrm{C}$ is observed to decrease by almost 2 times. This indicator decreases to $2 \mathrm{~g} /\left(\mathrm{m}^{2} \cdot \mathrm{h}\right)$. And at a temperature of $30{ }^{\circ} \mathrm{C}$, the corrosion rate is only $0.320234 \mathrm{~g} /\left(\mathrm{m}^{2} \cdot \mathrm{h}\right)$.

Water salinity significantly affects its corrosivity. As can be seen from the Table 1, with an increase in water 
salinity (replacing distilled water with tap water with all other equal salt concentrations), the corrosion rate of the metal increases to $4.71243 \mathrm{~g} /\left(\mathrm{m}^{2} \cdot \mathrm{h}\right)$. This is 1.67 times more than in the case of using a solution prepared in distilled water. And with an increase in the salt component of the solution $\left(100 \mathrm{~g} / \mathrm{dm}^{3}\right.$ of $\left.\mathrm{NaCl}\right)$, the corrosion rate of steel increases to $5.510204 \mathrm{~g} /\left(\mathrm{m}^{2} \cdot \mathrm{h}\right)$.

At the second stage of work, the effect of alkyl imidazolines on the corrosivity of oil aqueous solutions ( $\mathrm{P}-1$, P-2, P-3, P-3*, P-4, P-5) is determined (Fig. 1). The range of working concentrations is $\left(0-50 \mathrm{mg} / \mathrm{dm}^{3}\right)$.

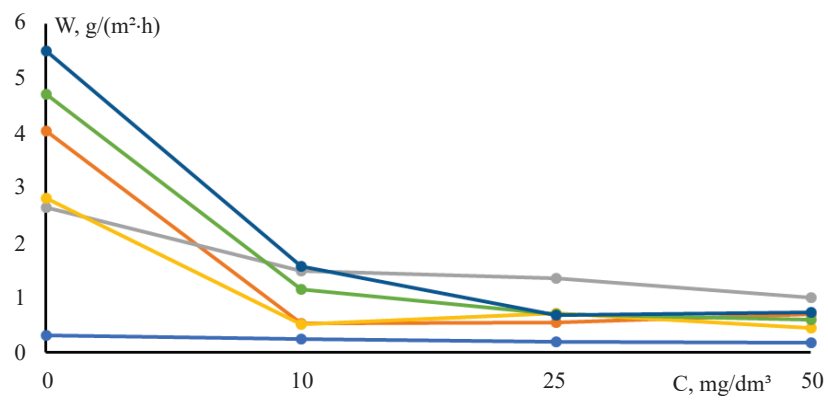

$\rightarrow \mathrm{P}-1 \quad \rightarrow \mathrm{P}-2 \quad \rightarrow \mathrm{P}-3 \rightarrow \mathrm{P}-3^{*} \rightarrow \mathrm{P}-4 \rightarrow \mathrm{P}-5$

Fig. 1. Reducing the corrosion rate of steel 20, depending on the composition of the initial solution P-1-P-5 (Table 1) and the concentration of alkyl imidazolines at a temperature of $80{ }^{\circ} \mathrm{C}$

The intensity of the decrease in the metal corrosion rate, as can be seen from Fig. 1 substantially depends on the aggressiveness of the output medium. The more aggressive the environment, the greater the manifestation of the effectiveness of alkyl imidazolines. For the most aggressive solution (P-5), the corrosion rate decreases from $5.510204 \mathrm{~g} /\left(\mathrm{m}^{2} \cdot \mathrm{h}\right)$ at a concentration of $0 \mathrm{mg} / \mathrm{dm}^{3}$ to $0.68323 \mathrm{~g} /\left(\mathrm{m}^{2} \cdot \mathrm{h}\right)$ at a concentration of $25 \mathrm{mg} / \mathrm{dm}^{3}$. The presence of oil in the solution naturally reduces the output aggressiveness of the water. The output corrosion rate of oil-containing solution is $2.820036 \mathrm{~g} /\left(\mathrm{m}^{2} \cdot \mathrm{h}\right)$. The use of alkyl imidazolines at a concentration of $10 \mathrm{mg} / \mathrm{dm}^{3}$ for such a solution leads to a decrease in the corrosion rate to $0.51948 \mathrm{~g} /\left(\mathrm{m}^{2} \cdot \mathrm{h}\right)$. And this is observed at a temperature of $80{ }^{\circ} \mathrm{C}$. For $30{ }^{\circ} \mathrm{C}$, firstly, the initial corrosion rate is insignificant $\left(0.320234 \mathrm{~g} /\left(\mathrm{m}^{2} \cdot \mathrm{h}\right)\right)$, secondly, when using alkyl imidazolines, it practically does not change and is $0.196878 \mathrm{~g} /\left(\mathrm{m}^{2} \cdot \mathrm{h}\right)$ with a dose of inhibitor of $25 \mathrm{mg} / \mathrm{dm}^{3}$.

To improve the effectiveness of alkyl imidazolines compositions based on them are developed. The efficacy of alkyl imidazolines+benzotriazole compositions in various ratios of components is determined. The results on the determination of the drag coefficient (DC) and the degree of protection against corrosion $(Z)$ are presented in Table 2 .

Results in Table 2 show that saline solutions containing sodium chloride are very aggressive in metal corrosion. The use of alkyl imidazolines as inhibitors of steel corrosion leads to metal protection. The maximum protective effect is observed at an inhibitor concentration of $10 \mathrm{mg} / \mathrm{dm}^{3}$. The degree of corrosion protection is $86.67 \%$. A further increase in the concentration of alkyl imidazolines slightly reduces the positive effect and at a concentration of $50 \mathrm{mg} / \mathrm{dm}^{3}$ the degree of protection against corrosion decreases to $82.52 \%$. Benzotriazole is a less effective inhibitor than alkyl imidazolines. Thus, at a concentration of $25 \mathrm{mg} / \mathrm{dm}^{3}$, the degree of corrosion protection is only $40.41 \%$. Com- positions based on alkyl imidazolines and benzotriazole do not lead to an increase in the degree of protection against corrosion, but are approximately the average value of this indicator, as is shown for individual components

Table 2

Dependencies of drag coefficient (DC) and degree of protection against corrosion $(Z)$ of steel 20 on the chemical composition of aqueous solutions and compositions at a temperature of $80^{\circ} \mathrm{C}$

\begin{tabular}{|c|c|c|c|c|}
\hline $\begin{array}{l}\text { Type } \\
\text { of so- } \\
\text { lution }\end{array}$ & Reagent & $\begin{array}{c}\text { Cor- } \\
\text { rosion } \\
\text { rate, } W \\
\mathrm{~g} /\left(\mathrm{m}^{2} \cdot \mathrm{h}\right)\end{array}$ & $\begin{array}{c}\text { Drag } \\
\text { coef- } \\
\text { ficient, } \\
K_{d}\end{array}$ & $\begin{array}{c}\text { Pratec- } \\
\text { tion } \\
\text { degree, } \\
Z, \%\end{array}$ \\
\hline \multirow{8}{*}{ P-1 } & - & 4.035251 & - & - \\
\hline & $10 \mathrm{mg} / \mathrm{dm}^{3}$ of alkyl imidazolines & 0.538033 & 7.50 & 86.67 \\
\hline & $25 \mathrm{mg} / \mathrm{dm}^{3}$ of alkyl imidazolines & 0.547310 & 7.37 & 86.43 \\
\hline & $50 \mathrm{mg} / \mathrm{dm}^{3}$ of alkyl imidazolines & 0.705009 & 5.72 & 82.52 \\
\hline & $25 \mathrm{mg} / \mathrm{dm}^{3}$ of benzotriazole & 2.404614 & 1.68 & 40.41 \\
\hline & $\begin{array}{l}10 \mathrm{mg} / \mathrm{dm}^{3} \text { of alkyl imidazolines } \\
10 \mathrm{mg} / \mathrm{dm}^{3} \text { of benzotriazole }\end{array}$ & 1.892393 & 2.13 & 53.10 \\
\hline & $\begin{array}{l}25 \mathrm{mg} / \mathrm{dm}^{3} \text { of alkyl imidazolines } \\
25 \mathrm{mg} / \mathrm{dm}^{3} \text { of benztriazole }\end{array}$ & 1.512059 & 2.67 & 62.53 \\
\hline & $\begin{array}{l}50 \mathrm{mg} / \mathrm{dm}^{3} \text { of alkyl imidazolines } \\
50 \mathrm{mg} / \mathrm{dm}^{3} \text { of benzotriazole }\end{array}$ & 1.512059 & 2.65 & 62.32 \\
\hline \multirow{4}{*}{ P-2 } & - & 2.643785 & - & - \\
\hline & $10 \mathrm{mg} / \mathrm{dm}^{3}$ of alkyl imidazolines & 1.493506 & 1.77 & 43.519 \\
\hline & $25 \mathrm{mg} / \mathrm{dm}^{3}$ of alkyl imidazolines & 1.354360 & 1.95 & 48.77 \\
\hline & $50 \mathrm{mg} / \mathrm{dm}^{3}$ of alkyl imidazolines & 1.066790 & 2.48 & 59.65 \\
\hline \multirow{6}{*}{ P-3 } & - & 2.820036 & - & - \\
\hline & $10 \mathrm{mg} / \mathrm{dm}^{3}$ of alkyl imidazolines & 0.51948 & 5.43 & 87.58 \\
\hline & $25 \mathrm{mg} / \mathrm{dm}^{3}$ of alkyl imidazolines & 0.71429 & 3.95 & 74.67 \\
\hline & $50 \mathrm{mg} / \mathrm{dm}^{3}$ of alkyl imidazolines & 0.45455 & 6.20 & 83.88 \\
\hline & $25 \mathrm{mg} / \mathrm{dm}^{3}$ of alkyl pyridines & 2.814410 & 1.01 & 0.216 \\
\hline & $\begin{array}{l}25 \mathrm{mg} / \mathrm{dm}^{3} \text { of alkyl imidazolines } \\
25 \mathrm{mg} / \mathrm{dm}^{3} \text { of alkyl pyridines }\end{array}$ & 0.825190 & 3.42 & 70.74 \\
\hline \multirow{6}{*}{$\mathrm{P}-3^{*}$} & - & 0.320234 & - & - \\
\hline & $10 \mathrm{mg} / \mathrm{dm}^{3}$ of alkyl imidazolines & 0.253128 & 1.27 & 20.96 \\
\hline & $25 \mathrm{mg} / \mathrm{dm}^{3}$ of alkyl imidazolines & 0.196878 & 1.63 & 38.52 \\
\hline & $50 \mathrm{mg} / \mathrm{dm}^{3}$ of alkyl imidazolines & 0.183555 & 1.75 & 42.68 \\
\hline & $25 \mathrm{mg} / \mathrm{dm}^{3}$ of benzotriazole & 0.234099 & 1.37 & 26.90 \\
\hline & $50 \mathrm{mg} / \mathrm{dm}^{3}$ of benzotriazole & 0.215692 & 1.49 & 32.65 \\
\hline \multirow{6}{*}{ P-4 } & - & 4.71243 & - & - \\
\hline & $10 \mathrm{mg} / \mathrm{dm}^{3}$ of alkyl imidazolines & 1.159555 & 4.06 & 75.39 \\
\hline & $+25 \mathrm{mg} / \mathrm{dm}^{3}$ of alkyl imidazolines & 0.695733 & 6.77 & 85.24 \\
\hline & $+50 \mathrm{mg} / \mathrm{dm}^{3}$ of alkyl imidazolines & 0.602968 & 7.82 & 87.21 \\
\hline & $+25 \mathrm{mg} / \mathrm{dm}^{3}$ of benzotriazole & 2.502218 & 1.88 & 46.90 \\
\hline & $+50 \mathrm{mg} / \mathrm{dm}^{3}$ of benzotriazole & 1.748004 & 2.70 & 62.91 \\
\hline \multirow{6}{*}{ P-5 } & - & 5.510204 & - & - \\
\hline & $25 \mathrm{mg} / \mathrm{dm}^{3}$ of alkyl imidazolines & 0.683230 & 8.07 & 87.60 \\
\hline & $25 \mathrm{mg} / \mathrm{dm}^{3}$ of benzotriazole & 1.889973 & 2.92 & 65.70 \\
\hline & $\begin{array}{l}10 \mathrm{mg} / \mathrm{dm}^{3} \text { of alkyl imidazolines } \\
10 \mathrm{mg} / \mathrm{dm}^{3} \text { of benzotriazole }\end{array}$ & 0.630798 & 8.74 & 88.55 \\
\hline & $\begin{array}{l}25 \mathrm{mg} / \mathrm{dm}^{3} \text { of alkyl imidazolines } \\
25 \mathrm{mg} / \mathrm{dm}^{3} \text { of benzotriazole }\end{array}$ & 0.575139 & 9.58 & 89.56 \\
\hline & $\begin{array}{l}50 \mathrm{mg} / \mathrm{dm}^{3} \text { of alkyl imidazolines } \\
50 \mathrm{mg} / \mathrm{dm}^{3} \text { of benzotriazole }\end{array}$ & 0.575139 & 9.58 & 89.56 \\
\hline
\end{tabular}

Note: ${ }^{*}$ - solution temperature $-30^{\circ} \mathrm{C}$ 
Mineralized water, in which sodium sulfite $(\mathrm{P}-2)$ is present, is less aggressive compared to solution $\mathrm{P}-1$. However, the effect of the use of alkyl imidazolines in this case is much less. At inhibitor concentrations of $10-50 \mathrm{mg} / \mathrm{dm}^{3}$, the degree of corrosion protection is in the range of $43-60 \%$.

Oil-containing mineralized solutions (P-3) are less aggressive in comparison with solutions without oil (P-1), but the corrosion rate in such solutions is still high (Table 1). Alkyl imidazolines in oil-containing solutions cause metal to be protected from corrosion. The optimal dose of the inhibitor is $10 \mathrm{mg} / \mathrm{dm}^{3}(Z=81.58 \%)$. A further increase in concentration does not contribute to the growth of the degree of protection against corrosion of steel 20 .

The use of alkyl pyridine as a steel corrosion inhibitor in oil-contained water has zero effect. The drag coefficient is 1.01. The presence of alkyl pyridine in the composition with alkyl imidazolines $\left(25 \mathrm{mg} / \mathrm{dm}^{3}\right.$ and $25 \mathrm{mg} / \mathrm{dm}^{3}$, respectively) does not improve the protective effect. The degree of protection against corrosion is practically the same as when using pure alkyl imidazolines $\left(25 \mathrm{mg} / \mathrm{dm}^{3}\right)$ and is $70.74 \%$.

Alkyl imidazolines and benzotriazole in the oil-containing solution demonstrate no significant protective effect. Thus, the inhibition rate for these inhibitors in concentrations of $10-50 \mathrm{mg} / \mathrm{dm}^{3}$ is in the range of 1.27-1.75. Large values of this indicator are characteristic of alkyl imidazolines. This corresponds to the degree of protection against corrosion at the level of $20.96-42.68 \%$.

With an increase in water salinity (P-4, P-5), the corrosion rate of the metal increases (Table 1 ). In such harsh conditions, alkyl imidazolines and benzotriazole provide a high degree of corrosion protection for steel. Alkyl imidazolines in concentrations of $10,25,50 \mathrm{mg} / \mathrm{dm}^{3}$ provide a drag coefficient of 4.06, 6.77, 7.81, respectively, which corresponds to the degree of protection of $75.39,85.24,87.21 \%$.

Benzotriazole as an inhibitor is less effective. The maximum effect $(Z=62.91 \%)$ corresponds to a dose of benzotriazole $50 \mathrm{mg} / \mathrm{dm}^{3}$.

With an increase in the concentration of salts in the solution, the protective effect slightly increases, and at a dose of $25 \mathrm{mg} / \mathrm{dm}^{3}$, the degree of protection for alkyl imidazolines increases to $87.60 \%$, and for benzotriazole to $65.70 \%$.

The combined use of alkyl imidazolines and benzotriazole for hard mineralized oil-containing water at a temperature of $80^{\circ} \mathrm{C}$ provides effective protection of the metal from corrosion. In compositions with a ratio of reagents $(10+10) \mathrm{mg} / \mathrm{dm}^{3},(25+25) \mathrm{mg} / \mathrm{dm}^{3},(50+50) \mathrm{mg} / \mathrm{dm}^{3}, \mathrm{drug}$ coefficient is $8.74-9.58$, which corresponds to the degree of corrosion protection $88.55-89.56 \%$.

The work also conducted studies to determine the effectiveness of the compositions to reduce the corrosivity of water when petroleum ether (petroleum ether, Sherwood oil) is used as a petroleum product. It is a mixture of light aliphatic hydrocarbons (pentane and hexane), obtained from associated petroleum gas and light oil frac- tions. The results to determine the effectiveness of the proposed inhibitors are given in Table 3 .

As can be seen from the Table 3 , with an increase in temperature from $30{ }^{\circ} \mathrm{C}$ to $80^{\circ} \mathrm{C}$, the corrosion rate in the mineralized solution with ether increases 10 times - from $0.311353 \mathrm{~g} /\left(\mathrm{m}^{2} \cdot \mathrm{h}\right)$ to $3.089054 \mathrm{~g} /\left(\mathrm{m}^{2} \cdot \mathrm{h}\right)$. The presence of sulfites in the solution also causes additional aggressiveness. At a temperature of $30^{\circ} \mathrm{C}$ and a concentration of sodium sulfite of $5 \mathrm{~g} / \mathrm{dm}^{3}$, the corrosion rate is $0.4204 \mathrm{~g} /\left(\mathrm{m}^{2} \cdot \mathrm{h}\right)$. This is due to the fact that petroleum ether is a volatile substance with a low evaporation temperature.

When used as an inhibitor of corrosion of steel alkyl imidazolines at a concentration of $50 \mathrm{~g} / \mathrm{dm}^{3}$, the degree of protection against corrosion is negligible and amounts to $31.379 \%$ for a temperature of $30^{\circ} \mathrm{C}$. And at $80{ }^{\circ} \mathrm{C}$, the protective effect disappears $\left(W=4.369202 \mathrm{~g} /\left(\mathrm{m}^{2} \cdot \mathrm{h}\right)\right)$. This is explained by the fact that when the temperature rises, the hydrophobic protective film on the metal surface is easily destroyed. This mixture of hydrocarbons is easily removed from the surface of the steel when heated using an inhibitor. The inhibitor itself can't create a protective film. In the presence of sodium sulfite in solution at a temperature of $30^{\circ} \mathrm{C}$, the inhibitory effect will appear slightly more due to the binding of oxygen by sulfite anions. The degree of corrosion protection is $45.305 \%$.

Table 3

Dependence of the degree of corrosion protection of steel 20 on the quantitative and qualitative composition of the initial solution and inhibitor, temperature ( $t=30^{\circ} \mathrm{C}$ (94 hours), $t=80^{\circ} \mathrm{C}$ (5 hours))

\begin{tabular}{|c|c|c|c|c|c|}
\hline Model solution & Reagent & $\begin{array}{c}\text { Tem- } \\
\text { perature } \\
t, \stackrel{\circ}{ }=\end{array}$ & $\begin{array}{l}\text { Corrosion } \\
\text { rate, } W \\
\mathrm{~g} /\left(\mathrm{m}^{2} \cdot \mathrm{h}\right)\end{array}$ & $\begin{array}{c}\text { Drug } \\
\text { coefficient, } \\
K_{d}\end{array}$ & $\begin{array}{c}\text { Protection } \\
\text { degree, } \\
Z, \%\end{array}$ \\
\hline \multirow{6}{*}{$\begin{array}{l}77 \mathrm{~cm}^{3} \text { of mineralized water: } \\
- \text { distilled water; } \\
-30 \mathrm{~g} / \mathrm{dm}^{3} \text { of } \mathrm{NaCl} ; \\
-3 \mathrm{~g} / \mathrm{dm}^{3} \text { of } \mathrm{CH}_{3} \mathrm{COOH} ; \\
-23 \mathrm{~cm}^{3} \text { of petroleum ther }\end{array}$} & - & 30 & 0.311353 & - & - \\
\hline & - & 80 & 3.089054 & - & - \\
\hline & \multirow{2}{*}{$\begin{array}{l}50 \mathrm{mg} / \mathrm{dm}^{3} \text { of alkyl } \\
\text { imidazolines }\end{array}$} & 30 & 0.213654 & 1.457 & 31.379 \\
\hline & & 80 & 4.369202 & $<1$ & - \\
\hline & \multirow{2}{*}{$\begin{array}{l}50 \mathrm{mg} / \mathrm{dm}^{3} \text { of alkyl } \\
\text { pyridines }\end{array}$} & 30 & 0.383393 & $<1$ & - \\
\hline & & 80 & 7.1872223 & $<1$ & - \\
\hline \multirow{3}{*}{$\begin{array}{l}77 \mathrm{~cm}^{3} \text { of mineralized water: } \\
\text { - distilled water; } \\
-30 \mathrm{~g} / \mathrm{dm}^{3} \text { of } \mathrm{NaCl} ; \\
-3 \mathrm{~g} / \mathrm{dm}^{3} \text { of } \mathrm{CH}_{3} \mathrm{COOH} ; \\
-5 \mathrm{~g} / \mathrm{dm}^{3} \text { of } \mathrm{Na}_{2} \mathrm{SO}_{3} ; \\
-23 \mathrm{~cm}^{3} \text { of petroleum ether }\end{array}$} & - & \multirow{3}{*}{30} & 0.4204 & - & - \\
\hline & $\begin{array}{l}50 \mathrm{mg} / \mathrm{dm}^{3} \text { of alkyl } \\
\text { imidazolines }\end{array}$ & & 0.229937 & 1.828 & 45.305 \\
\hline & $\begin{array}{l}50 \mathrm{mg} / \mathrm{dm}^{3} \text { of alkyl } \\
\text { pyridines }\end{array}$ & & 0.328129 & 1.281 & 21.948 \\
\hline
\end{tabular}

The use of alkyl pyridines $\left(\mathrm{mg} / \mathrm{dm}^{3}\right)$ as steel corrosion inhibitors does not lead to a positive effect (Table 1). On the contrary, this reagent causes an increase in metal corrosion. Only in the presence of sodium sulfite at $30{ }^{\circ} \mathrm{C}$ there is a slight result. The degree of protection in this case is $21.948 \%$

\section{SWOT analysis of research results}

Strengths. Inhibitors based on alkyl imidazolines are promising not only in oil refining, but also in protecting pipelines and equipment from corrosion in an aquatic environment with a high level of mineralization. In the presence of oil and oil products in significant concentrations due to the adsorption of the imidazolined nitrogen-containing rings on the metal, its surface is hydrophobized by the hydrocarbon radicals of imidazolines. This leads to the formation of a durable hydrocarbon film on the metal, 
which reliably protects it from corrosion. The advantage of alkyl imidazolines is that due to the hydrophilic and hydrophobic components of their molecules, they dissolve well in both petroleum products and in the aquatic environment. It provides their high efficiency both in water in the presence of oil products, and in oil, in the presence of water.

Weaknesses. The main disadvantage of alkyl imidazolines based inhibitors is their relatively high cost, since one of the main components of their synthesis is polyethylene polyamine, which is currently not produced in Ukraine. Therefore, their price in the market is quite high.

Opportunities. In the case of the use of corrosion inhibitors of steel on the basis of alkyl imidazolines, it is possible to achieve high effectiveness of protection against destruction of oil pipelines, where, in addition to oil, there are always impurities of saline water, and water pipelines, where oil contains in highly mineralized waters. In addition, when using production wastes - tall oil acids, or when using vegetable oils instead of synthetic carboxylic acids in alkyl imidazoline production, their cost can be significantly reduced.

Threats. Considering that pipelines through which oil or mineralized water is transported are also used in the winter period, there is a risk of freezing, crystallization or considerable thickening of imidazolines during storage in unheated warehouses. To prevent this, they must be used in the form of $40-50 \%$ solutions in kerosene.

\section{Conclusions}

1. The corrosivity of compositions of different wateroil-mineral composition was determined. It is shown that mineralized aqueous solutions are more corrosively aggressive than their composition with oil. The corrosion rate of saline water, depending on the concentration of salts, varies between $4.035251-5.510204 \mathrm{~g} /\left(\mathrm{m}_{2} \cdot \mathrm{h}\right)$. For oilcontaining emulsions, this indicator is $2.820036 \mathrm{~g} /\left(\mathrm{m}_{2} \cdot \mathrm{h}\right)$. To a certain extent, the corrosivity of mineralized aqueous solutions decreases in the presence of sodium sulfite $\left(W=2.6443785 \mathrm{~g} /\left(\mathrm{m}_{2} \cdot \mathrm{h}\right)\right)$.

2. It is shown that the alkyl imidazoline-based inhibitor provides high efficiency of protecting steel against corrosion in mineralized water-oil emulsion at temperatures from $30^{\circ} \mathrm{C}$ to $80^{\circ} \mathrm{C}$. The degree of protection at doses of $10-50 \mathrm{mg} / \mathrm{dm}^{3}$ reaches $82-86 \%$. The use of benzotriazole is less effective.

3. It is established that inhibitors based on alkyl imidazoline in aqueous-organic emulsions based on saline water and petroleum ether are effective only at low temperatures. At a temperature of $30{ }^{\circ} \mathrm{C}$, the degree of corrosion protection is $31.379-45.305 \%$. At elevated temperatures, due to the high volatility of petroleum ether, the formation of a protective adsorption film on the surface of the steel does not occur. Accordingly, there is no protective effect.

\section{References}

1. New inhibitors of corrosion and depositions of sediments for water circulation systems / Gomelya N. D. et. al. // Journal of Water Chemistry and Technology. 2017. Vol. 39, Issue 2. P. 92-96. doi: http://doi.org/10.3103/s1063455x17020060

2. Homelia M. D., Radovenchyk V. M., Shablii T. O. Suchasni metody kondytsionuvannia ta ochystky vody v promyslovosti: monograph. Kyiv: Hrafika, 2007. 168 p.
3. Paher S. M., Herasymenko Yu. S. Modyfikatsiia karbonatnonakypnykh osadiv dlia zakhystu vid korozii teploobminnoi poverkhni // Visnyk Skhidnoukrainskoho natsionalnoho universytetu imeni Volodymyra Dalia. 2013. Issue 13. P. 54-65.

4. Sokolov L. I. Pererabotka i utilizatsiya neftesoderzhashhikh otkhodov: monograph. Moscow: Infra-Inzheneriya, 2017. 160 p.

5. Zlydnev N. N., Es'kin A. A., Tkach N. S. Istochniki neftesoderzhashhikh vod: Proceedings // Tekhnicheskie nauki - ot teorii k praktike. Novosibirsk: SibAK, 2014. Issue 7 (32). URL: https://sibac.info/conf/tech/xxxvi/38910

6. Corrosion inhibition of N80 steel simulated in an oil field acidification environment / Du J. et. al. // International Journal of Electrochemical Science. 2018. Vol. 13, Issue 6. P. 5810-5823. doi: http://doi.org/10.20964/2018.06.69

7. Sharma P., Roy H. Mill scale corrosion and prevention in carbon steel heat exchanger // High temperature materials and processes. 2015. Vol. 34, Issue 6. P. 571-576. doi: http://doi.org/ 10.1515/htmp-2014-0115

8. Calcium alginate gel capsules loaded with inhibitor for corrosion protection of downhole tube in oilfields / Wang L. et. al. // Corrosion Science. 2015. Vol. 90. P. 296-304. doi: http://doi.org/ 10.1016/j.corsci.2014.10.026

9. Evaluation of ferrous carbonate/iron oxides scaling risk under high temperature in the absence and presence of scale inhibitors: proceedings / Yang C. et. al. // SPE International Symposium on Oilfield Chemistry. The Woodlands, 2015. Vol. 2. P. 1080-1092. doi: http://doi.org/10.2118/173785-ms

10. Deyab M. A. Corrosion inhibition of heat exchanger tubing material (titanium) in MSF desalination plants in acid cleaning solution using aromatic nitro compounds // Desalination. 2018. Vol. 439. P. 73-79. doi: http://doi.org/10.1016/ j.desal.2018.04.005

11. Synthesis and Characterization of Modified Aliphatic Polycarbonates as Environmentally Friendly Oilfield Scale Inhibitors / Mady M. F. et. al. // Energy \& Fuels. 2018. Vol. 32, Issue 6. P. 6746-6755. doi: http://doi.org/10.1021/ acs.energyfuels. $8 \mathrm{~b} 01168$

Shuryberko Mariia, Postgraduate Student, Department of Ecology and Plant Polymers Technology, National Technical University of Ukraine «Igor Sikorsky Kyiv Polytechnic Institute», Ukraine, e-mail: mashashuryberko@gmail.com, ORCID: http://orcid.org/0000-00015283-2069

Gomelya Mykola, Doctor of Technical Sciences, Professor, Head of the Department of Ecology and Plant Polymers Technology, National Technical University of Ukraine «Igor Sikorsky Kyiv Polytechnic Institute»,Ukraine, e-mail:m.gomelya@kpi.ua, ORCID: http://orcid.org/ 0000-0003-1165-7545

Gluchenko Nikola, Senior Lecturer, Department of Operations Management Units with Military Communications Facilities, National Academy of National Guard of Ukraine, Kharkiv, Ukraine, e-mail: gluschenko4@ukr.net, ORCID: http://orcid.org/0000-00033448-0965

Chuprova Kristina, Department of Ecology and Plant Polymers Technology, National Technical University of Ukraine «Igor Sikorsky Kyiv Polytechnic Institute»,Ukraine, e-mail: istiupro@gmail.com, ORCID: http://orcid.org/0000-0002-4713-3949

Overchenko Tetiana, PhD, Department of Ecology and Plant Polymers Technology, National Technical University of Ukraine «Igor Sikorsky Kyiv Polytechnic Institute»,Ukraine, e-mail: nezvyskaya@i.ua, ORCID: http://orcid.org/0000-0002-5883-6228 